\title{
尿中濃度を用いたパラコート中毒の重症度指数設定に関する研究
}

鹿児島大学医学部泌尿器科教室（主任：大井好忠教授）

山下淳 一

\section{CLINICAL STUDIES ON PARAQUAT POISONING; PROGNOSIS AND SEVERITY INDEX OF PARAQUAT POSISONING USING THE URINE LEVELS}

\author{
Jun-ichi Yamashita \\ Department of Urology, School of Medicine, Kagoshima University \\ (Director: Prof. Yoshitada Ohi)
}

The prognosis of paraquat poisoning has been assessed from serum paraquat levels using e.g. produfoot survival curve.

The prognosis of paraquat poisoning has not been investigated from urinary paraquat levels. The purpose of this study is to clarify whether the prognosis of paraquat poisoning can be determined by urinary paraquat levels or not. Urinary severity index of paraquat poisoning (U-SIPP) was employed. U-SIPP is calculated as hours between ingestion of paraquat and start of intensive treatment multiplied by the paraquat level in the urine at the same time. Urinary excretion of paraquat is correlated with renal function. The prognosis of paraquat poisoning using U-SIPP was further discussed, based on creatinine clearance $(\mathrm{Ccr})$ and the relation between serum and urine paraquat levels.

The following results were obtained.

1) When creatinine clearance was greater than $20 \mathrm{ml} / \mathrm{min}$, patients who died of ciculatory failure were with U-SIPP level over 1250, patients who died of respiratory failure were with U-SIPP level between 1250 and 250, and survivors were with U-SIPP below 250.

2) Survival duration was closely correlative with U-SIPP in cases with Ccr greater than 20 $\mathrm{ml} / \mathrm{min}(\mathrm{r}=-0.8123, \mathrm{p}<0.025)$.

3) When $\mathrm{Ccr}$ was greater than $20 \mathrm{ml} / \mathrm{min}$, urinary paraquat levels were correlated very well with the serum levels at admission, even during direct hemoperfusion (DHP) treatment.

4) When diuretic agents such as furosemide was effective, the assessment of the prognosis of paraquat poisoning using urinary paraquat levels seemed to be possible. Urinary paraquat level was approximately measured by an applied qualitative analysis method with using a dilution method.

要旨：従来パラコート中毒患者の予後予測には血清中パラコート濃度を基準とした指標が用いられてお り，数量的に明示可能な重症度の新しい指標として SIPP (severity index of paraquat poisoning, 来 院時血清パラコート濃度×服毒から集中治療開始までの時間）を報告した。しかし，尿中パラコート濃 度を用いて検討した報告はみられていない。尿中パラコート濃度を指標として予後予測ができなかった 理由として，腎機能低下に伴って尿中パラコート排泄能も低下すること，尿中パラュート濃度から予後 予測を行らための客観的な指標がなかったことが原因としてあげられる.そこで, SIPP と同様に尿中か ら重症度を評価する指標として U-SIPP (urinary severity index of paraquat poisoning, 来院時尿中 パラコート濃度×服毒から集中治療開始までの時間）を考案し腎障害の程度の指標としてクレアチニ ン・クリアランス (Ccr) を用いることによって，尿中パラコート濃度からパラコート中毒患者の予後の 予測が可能か否かについて検討を行った，血清中パラコート濃度を用いた場合の検討結果と比較し以下 の結論を得た。

1）生存群, 呼吸不全死群, 循環不全死群で分類した予後 3 群は $\mathrm{Ccr} \geqq 20 \mathrm{ml} / \mathrm{min}$ であれば SIPP と同様 
にU-SIPPによっても明瞭に分類可能であった。

2) $\mathrm{Ccr} \geqq 20 \mathrm{ml} / \mathrm{min}$ であれば生存時間とU-SIPP との間には強い負の相関がみられた。

3) $\mathrm{Ccr} \geqq 20 \mathrm{ml} / \mathrm{min}$ であれば初診時の血清中パラコート濃度と尿中パラコート濃度間には強い正の相 関がみられた。

4) $\mathrm{Ccr} \geqq 20 \mathrm{ml} / \mathrm{min}$ であれば, DHP 治療中でも血清中パラコート濃度と尿中パラコート濃度間には強 い正の相関がみられた。

5）利尿剂に充分反応すれば，尿中パラコート定性分析を応用した定性希釈比色法 (半定量法) でパラ コート中毒患者の予後予測が可能であるとおもわれた.

\section{緒 言}

パラコートは1955年に英国で開発された bipyridylium 系の除草剂であり，1962年に市販されて以来 その強力な除草効果により急速に世界各国に普及し, 本邦では1965年に発売された。使用法の簡便さと強力 な除草効果のために現在最も多く使用されている除草 剤の一つである。 パラコート散布中の中毒例の発生は 現在のところ報告はないが，领用すると強い毒性を発 揮する，入手が容易であることから近年本剂による自 殺企図ならびに事故が相次いでいる122.

このような事故防止のために，1979年には中权性催 吐剤の添加, 1983年には濃青緑色の着色（グラモキン ン S), 1985年には警戒臭の添加により不慮の事故防止 対策がなされてきた。それにもかかわらず本剤による 中毒症例は続発して抢り，また極めて強い毒性発現の ために有効な治療法がないのが現状であり救命率は極 めて低い3).

パラコートによる本邦の死亡数は1985年には1,021 例に達し, 自殺が985例, 事故または殺人が36例であっ た4)。また, 1986年 7 月からパラコート濃度は $24 \%$ から $5 \%$ に希䣋され，本剤による中毒予防対策も講じられ ている1).

パラコート中毒症例の予後の予測には従来 Proudfoot の生存曲線5が使用されているが客観的数量的に その予後を評価しにくい欠点があった，そこで，新し くパラコート重症度指数 (Severity Index of paraquat poisoning 以下 SIPP と略す)を試案し，その有用性に ついては既に報告した ${ }^{6) 7}$. しかし，すべて血清中パラ コート濃度からの解析であった。 そこで, 今回尿中パ ラコート濃度から予後を推測することが可能か否かに ついて検討したのでその成績について報告する。

\section{対象と方法}

1985年 7 月から1987年 9 月までの 2 年 2 カ月間に鹿 览島大学附属病院救急部に担送されたパラコート中毒 患者34例を対象とした（Table 1).
34例中救命し得た症例は10例（29.4\%）であった。 死亡例は 24 例であり, 死亡原因は臨床的に循環不全死 14例 (58.3\%) 呼吸不全死10例（41.7\%）の 2 群に大 別された。性別では, 男性23例, 女性11例であった。 平均年齢は, 43.9歳であり, 服毒例はすべて精神障害 者または自殺企図によるものであった，服毒したパラ コートはグラモキンン（パラコート濃度 $24 \%$ ）であっ た。

治療は原則として強制利尿，胃・腸管洗浄を行うと 共に, 出来る限り早期に direct hemoperfusion（以下 DHP と略す) を施行した. DHP カラムは $4 \sim 6$ 時間 毎に交換することを原則とし，血清中と尿中パラコー ト濃度が測定不能になるまで施行した。 また, DHP 施 行の limiting factorを血小板 5 万 $/ \mathrm{mm}^{3}$ とし，それ以 下になった場合には中止した. ステロイド大量療法, vitamin $\mathrm{E}$, glutathion, cyclophosphamide ${ }^{8) \sim 10)}$ の投 与も行った。

初診時に血清中パラコート濃度を測定し得たのは症 例 4 以降の 31 例, 初診時尿中濃度測定を施行し得たの は，18例であった。

パラコート濃度の測定方法 ${ }^{11}$

パラコートの血清中濃度測定には sodium hydrosalfite (dithionite 反応)を用いた呈色反応によ り吸光度を測定した。分離した血清 $2 \mathrm{ml} に$ に, 抽出液(ク ロロホルム：エタノール $=4: 1) 2 \mathrm{ml}$, 硫酸アンモ二 ウム $1.2 \mathrm{~g}$ を加兄, 30 秒間擋拌した。擋拌後 $3,000 \mathrm{rpm}$ で 10 分間遠心分離し，クロロホルム層と水層の 2 層に分 離した。 パラコートは水溶性が高く上方のエタノー ル・水層に含まれるので, その上清を $1.4 \mathrm{ml}$ とり, $1 \%$ sodium hydrosalfite 含有 $0.1 \mathrm{~N} \mathrm{NaOH}$ 容液 $0.2 \mathrm{ml}$ を 添加し，直ちに $395 \mathrm{~nm}$ で吸光度を測定した。測定に用 いた機種は, HITACHI 150-20型ダブルビーム分光光 度計である，対照は，パラコート非含有血清を同様に 処理したものを用いた。この方法でのパラコート回収 率は91.7士5.8\%（n=5）であった。 
Table 1 パラコート中毒症例

\begin{tabular}{|c|c|c|c|c|c|c|c|c|c|c|}
\hline No. & 性別 & 年齢 & $\begin{array}{l}\text { 推定服毒 } \\
\text { 量 } \mathrm{ml}\end{array}$ & 予後 & 生存時間 & $\begin{array}{l}\text { 治療開始 } \\
\text { 時間 } \mathrm{hr}\end{array}$ & $\begin{array}{r}\text { 血中濃度 } \\
\mu \mathrm{g} / \mathrm{ml}\end{array}$ & $\begin{array}{r}\text { 尿中濃度 } \\
\mu \mu \mathrm{g} / \mathrm{ml}\end{array}$ & SIPP & U-SIPP \\
\hline 1 & M & 66 & 200 & 循環不全 & 19時間 & 5 & - & - & & \\
\hline 2 & M & 40 & 180 & 循環不全 & 25時間 & 2 & - & - & & \\
\hline 3 & M & 20 & 10 & 呼吸不全 & 33日 & 1 & - & - & & \\
\hline 4 & $\mathrm{~F}$ & 36 & 90 & 循環不全 & 3日 & 27 & 1.4 & - & 37.8 & \\
\hline 5 & $\mathrm{~F}$ & 35 & 35 & 循環不全 & 3日 & 1 & 54.5 & 1400 & 54.5 & 1400 \\
\hline 6 & M & 49 & 100 & 循環不全 & 4日 & 5 & 58.5 & - & 292.5 & \\
\hline 7 & $\mathrm{~F}$ & 16 & 6 & 生存 & & 8 & 0.15 & 7.1 & 1.2 & 56.8 \\
\hline 8 & M & 42 & 60 & 呼吸不全 & 29日 & 5 & 2.1 & 155 & 10.5 & 775 \\
\hline 9 & $\mathrm{~F}$ & 33 & 15 & 呼吸不全 & 11日 & 5 & 5.2 & 63 & 26 & 315 \\
\hline 10 & M & 20 & 10 & 呼吸不全 & 18日 & 100 & 0.4 & 0.64 & 40 & 64 \\
\hline 11 & M & 51 & 不明 & 呼吸不全 & 6日 & 10 & 2.8 & 12.8 & 28 & 128 \\
\hline 12 & M & 41 & 100 & 循環不全 & 2日 & 4 & 19.5 & 440 & 78 & 1760 \\
\hline 13 & M & 42 & 25 & 生存 & & 4 & 1.4 & 10 & 5.6 & 40 \\
\hline 14 & M & 63 & 300 & 循環不全 & 18時間 & 4 & 47.5 & - & 190 & \\
\hline 15 & M & 41 & 不明 & 生存 & & 2 & 0.5 & 3.4 & 1.1 & 6.8 \\
\hline 16 & M & 59 & 不明 & 生存 & & 37 & 0.1 & 1.2 & 3.7 & 44.4 \\
\hline 17 & M & 20 & 不明 & 呼吸不全 & 9日 & 7 & 4.5 & - & 31.5 & \\
\hline 18 & $\mathrm{~F}$ & 41 & 不明 & 呼吸不全 & 50 日 & 4 & 3.5 & 70 & 14 & 280 \\
\hline 19 & M & 65 & 不明 & 生存 & & 41 & 0.2 & 0.2 & 0.8 & 0.86 \\
\hline 20 & M & 56 & 200 & 循環不全 & 5時間 & 2 & 300 & - & 600 & \\
\hline 21 & $\mathrm{~F}$ & 71 & 不明 & 循環不全 & 1日 & 4 & 60 & - & 240 & \\
\hline 22 & $\mathrm{~F}$ & 47 & 300 & 循環不全 & 20時間 & 5 & 100 & - & 500 & \\
\hline 23 & $\mathrm{~F}$ & 45 & 180 & 循環不全 & 2日 & 10 & 6 & - & 60 & \\
\hline 24 & M & 51 & 70 & 循環不全 & 40時間 & 19 & 9 & - & 171 & \\
\hline 25 & M & 30 & 10 & 生存 & & 15 & 0.1 & - & 1.2 & \\
\hline 26 & $\mathrm{~F}$ & 28 & 10 & 生存 & & 28 & $<0.1$ & 0.1 & 1.4 & 2.8 \\
\hline 27 & M & 62 & 不明 & 循環不全 & 21時間 & 3 & 45 & 900 & 135 & 2700 \\
\hline 28 & M & 45 & 5 & 生存 & & 2 & 0.1 & - & 0.2 & \\
\hline 29 & M & 35 & 不明 & 生存 & & 192 & $<0.1$ & - & 1.92 & \\
\hline 30 & M & 54 & 100 & 循環不全 & 13時間 & 4 & 45 & - & 180 & \\
\hline 31 & $\mathrm{~F}$ & 33 & 不明 & 生存 & & 65 & $<0.1$ & 1.1 & $<6.5$ & 71.5 \\
\hline 32 & $\mathrm{~F}$ & 72 & 不明 & 呼吸不全 & 40日 & 2.5 & 4.5 & 220 & 11.3 & 550 \\
\hline 33 & M & 44 & 14 & 呼吸不全 & 40日 & 4 & 3.3 & 200 & 13.2 & 800 \\
\hline 34 & M & 40 & 不明 & 呼吸不全 & 10日 & 90 & 0.5 & 1.5 & 45 & 135 \\
\hline
\end{tabular}

パラコートの吸光度はアルカリ性条件下, stdium hydrosalfite 添加で紫外部 $395 \mathrm{~nm}$ と可視部603nm に ピークがみられるが, 定量的には $395 \mathrm{~nm}$ を用いて測定 した (Fig. 1)。検量線の作成には血清を用いたパラ コート希釈系列液を使用した。パラコート濃度 $0.1 \sim 1.0 \mu \mathrm{g} / \mathrm{ml}$ では直線的であるが, $1 \sim 10 \mu \mathrm{g} / \mathrm{ml}$ で は上昇率は低下する (Quenching 現象)。そのため, 高 濃度の場合は希釈して測定した。

尿中濃度測定も同様に行った。尿中濃度は高濃度の 場合が多いので希釈後に測定を行った，尿の希釈にあ たっては蒸留水を用いて10倍希釈系列であらかじめ $10^{4}$ 倍まで濃度測定の後適切な濃度に希釈してその2 $\mathrm{ml}$ をとり, $1 \%$ sodium hydrosalfite 含有 $0.1 \mathrm{~N} \mathrm{NaOH}$ 溶液 $1 \mathrm{ml}$ を加え, 直ちに $395 \mathrm{~nm}$ の吸光度を血清サンプ ルと同様に測定した。対照としては希釈後無処置の同 一尿 $2 \mathrm{ml}$ を用いた。検量線作成にはパラコート水溶液 を用いた。 また，利尿剤に反応して尿量が充分得られ た症例ではパラコート定性分析法 ${ }^{17)}$ 応用して, 比色 法による半定量的測定を試みた。

\section{U-SIPP の検討方法}

尿中パラコート濃度から予後の予測を行らについて は，血清中パラコート濃度から重症度指数 (SIPP) を 検討したのと同様に，尿中パラコート濃度から重症度 指数 (以下 U-SIPP) を試案し検討を抗こなった。重症 
Fig. 1 パラコートラジカル吸収スペクトル

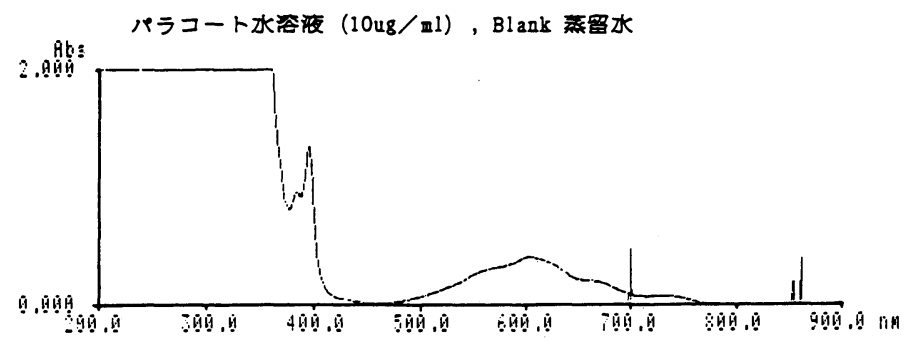

度指数についてはそれぞれ以下のごとく規定した。 血清パラコート濃度からの重症度指数

Severity Index of Paraquat Poisoning (SIPP) $\mathrm{SIPP}=$ 来院時血清パラコート濃度 $\times$ 服毒から集中 治療開始（来院時）までの時間

尿中パラコート濃度からの重症度指数

Urinary Severity Index of Paraquat Poisoning (U-SIPP)

$\mathrm{U}-\mathrm{SIPP}=$ 来院時尿中パラコート濃度 $\times$ 服毒から集 中治療開始（来院時）までの時間

また，パラコートの尿中排泄は腎機能低下に伴い低 下すると考えられるので, 腎機能の評価として, クレ アチニン・クリアランス（以下 Ccr）をもちいて比較検 討をおこなった. $\mathrm{Ccr}$ の測定には初診時から $2 \sim 8$ 時 間まで蓄尿した尿検体のクレアチニン値とその間に採 血した血清クレアチニン值を用いた.

\section{成績}

1) SIPP と生存期間

SIPP と生存期間の関係を示した(Fig. 2). SIPP と 生存期間の間には強い負の相関が得られた。

2) U-SIPP と生存期間

初診時に尿中パラコート濃度を測定できた18例の生 存期間と U-SIPP の関係を Fig. 3 に示した。

生存群, 呼吸不全死群, 循環不全死群の 3 群はUSIPP 100 と1,000を境界としてほぼ分類できた。呼吸 不全死群之循環不全死群の死亡例11例についてUSIPP と生存期間の相関について検討した. しかし, 両 者間には相関は認められなかった。

そこで，パラコートの尿中排泄能も他の物質と同様 に腎機能に依存すると考兄られるため, 腎機能の指標 として Ccrを用い Ccr $\geqq 20 \mathrm{ml} / \mathrm{min}$ の症例について相 関を検討した。死亡例で $\mathrm{Ccr} \geqq 20 \mathrm{ml} / \mathrm{min}$ の症例は 8 例みられた。 この 8 例についての相関を検討すると, $\mathrm{r}=-0.8213 （ \mathrm{p}<0.025 ）$ と強い負の相関を示した.
Fig. 2 SIPP と生存期間

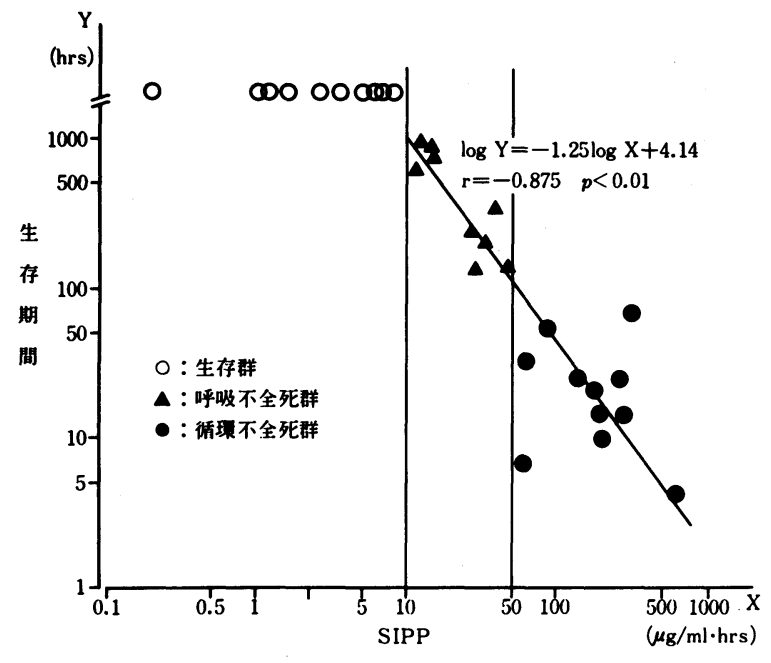

3) SIPP とU-SIPP の比較

SIPP と U-SIPP との相関について検討した. Fig. 4 のごとく, SIPP とU-SIPP は正の相関を示寸傾向が みられた $(\mathrm{r}=0.757) . \mathrm{Ccr} \geqq 20 \mathrm{ml} / \mathrm{min}$ の13例について 検討すると, $\mathrm{r}=0.908(\mathrm{p}<0.005)$ と更に強い相関を 示した.

4）尿中・血清中パラコート濃度の相関

尿中パラコート濃度と, 血清中パラコート濃度との 相関について $\mathrm{Ccr} \geqq 20 \mathrm{ml} / \mathrm{min}$ の症例において検討し た.この条件で初診時尿中・血清中パラコート濃度を 同時に測定し得た症例は13例であった（Fig. 5).

相関係数 $\mathrm{r}=0.946(\mathrm{p}<0.01)$ と, 強い正の相関を示 した。 また， $\mathrm{Cr}<20 \mathrm{ml} / \mathrm{min} て ゙$ 尿中・血清中パラコー ト濃度を測定し得た症例は 5 例であった。この 5 例間 には相関はみられなかった。

5）治療中の血清中・尿中パラコート濃度の相関

DHP 治療中の血清中・尿中パラコート濃度の推移 
Fig. 3 U-SIPP と生存期間

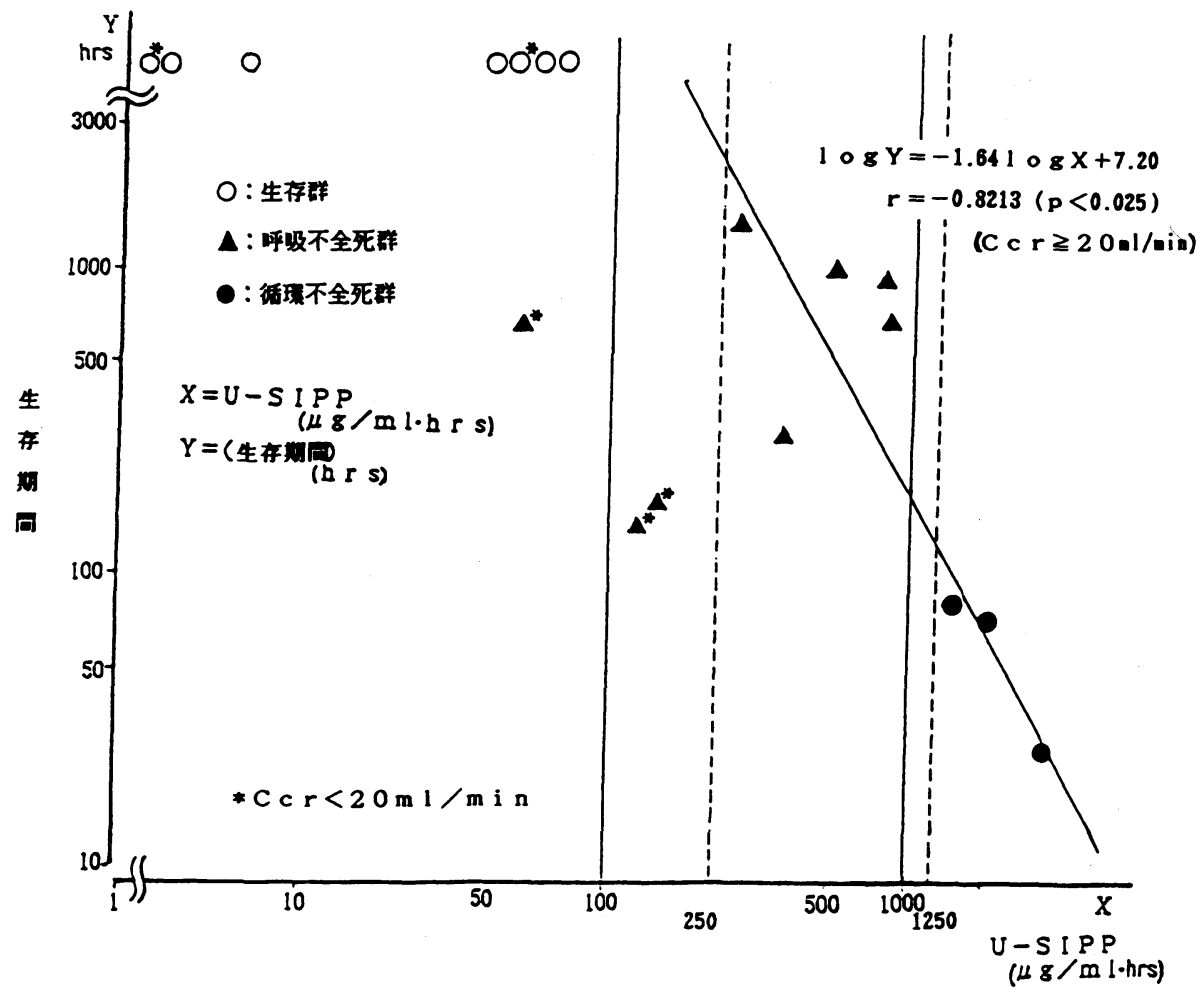

Fig. 4 SIPP と U-SIPP

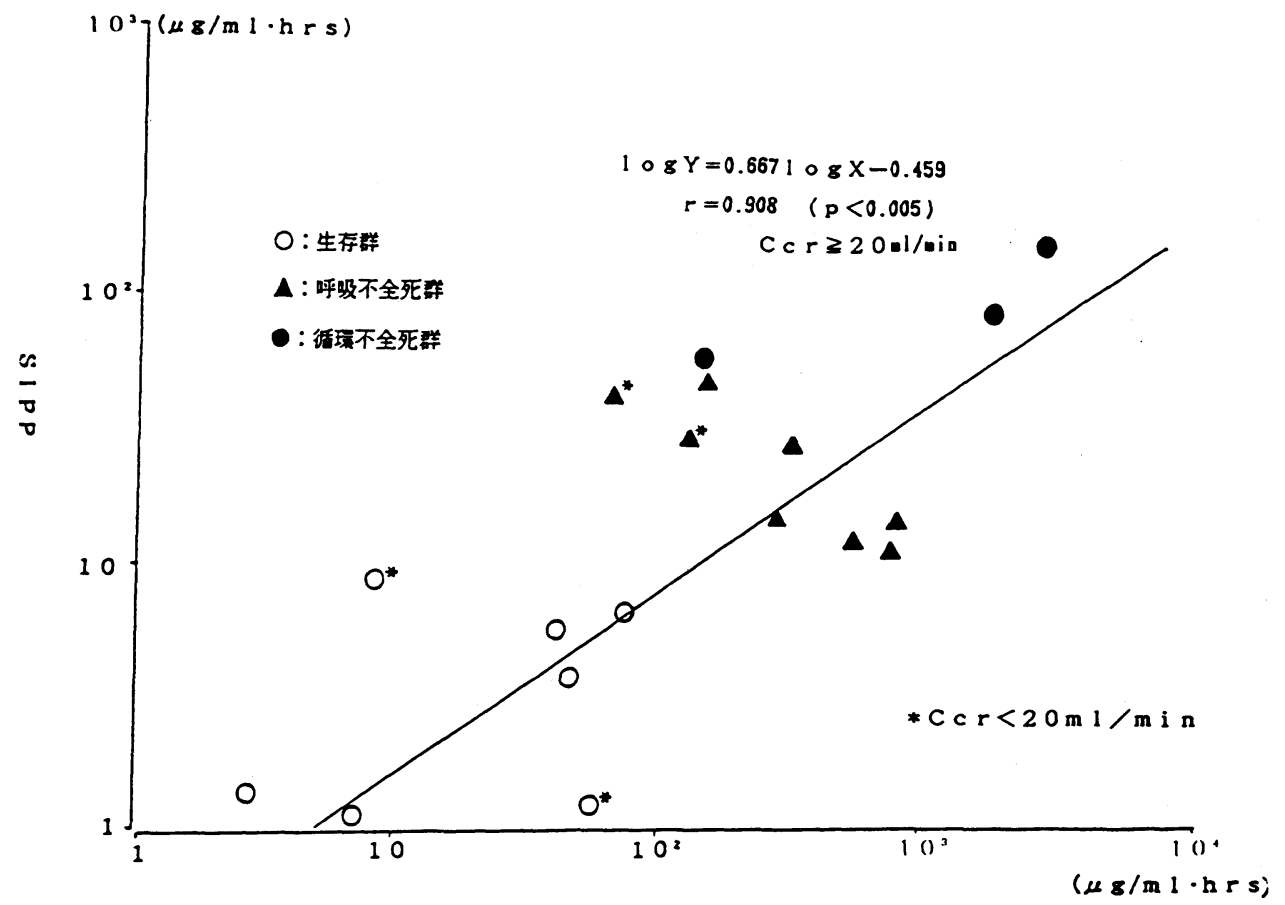


Fig. 5 堅機能 $\mathrm{Ccr} \geqq 20 \mathrm{ml} / \mathrm{min}$ での血清中・尿中パラ コート濃度の相関

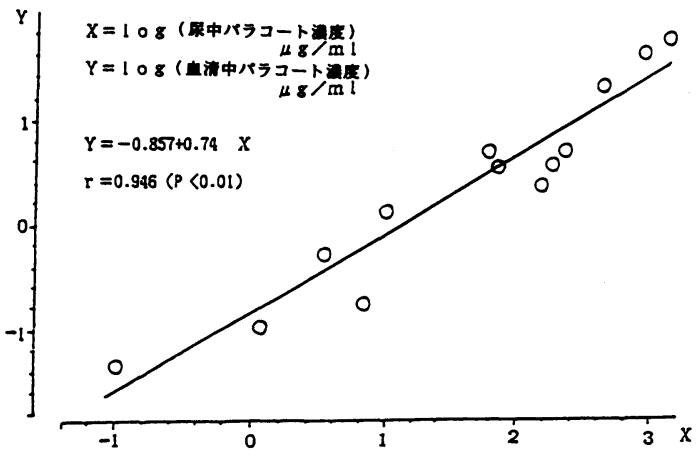

Fig. 6 治療中のパラコート中毒患者, 症例 No. 5に おける腎機能 $\mathrm{Ccr} \geqq 20 \mathrm{ml} / \mathrm{min}$ での血清中・尿中パ ラコート濃度の相関

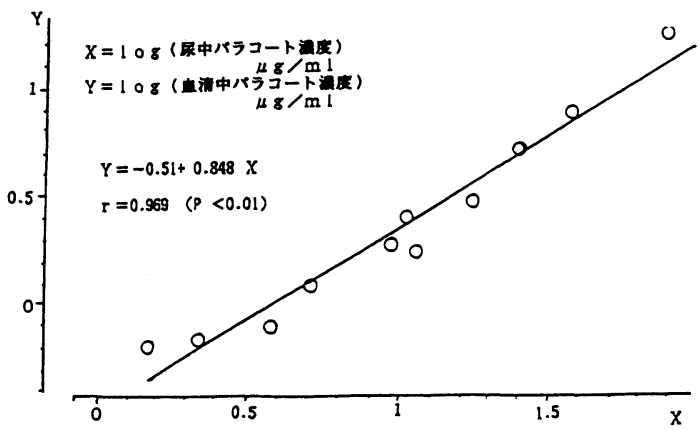

を連続的に測定できた 1 例（No. 5）について検討し た. 腎機能 $\mathrm{Ccr} \geqq 20 \mathrm{ml} / \mathrm{min}$ の時には血清中・尿中濃度 は相関係数 $\mathrm{r}=0.969(\mathrm{p}<0.01)$ と強い正の相関を示し た (Fig. 6).

本症例はその後腎機能障害をきたしたが, $\mathrm{Ccr}<20$ $\mathrm{ml} / \mathrm{min}$ の場合には血清中・尿中パラコート濃度の相 関はみられなかった（Fig. 7).

6）尿中パラコート濃度の比色定性法による半定量 法の成績

来院時尿中パラコート濃度を測定できた 5 例（No. $5,8,12,32,33)$ について希釈比色法により肉眼的 に半定量をおこなった (Table 2). その結果, 比色定 量法との間の誤差は $11.7 \pm 2.6 \%$ あり,いずれも比色 定量法よりも低値を示した。

\section{考察}

パラコートの毒性は強く, 人における推定致死量は $40 \sim 50 \mathrm{mg} / \mathrm{kg}$ と考えられて拈り $24 \%$ 濃度の本剤では
Fig. 7 治療中パラコート中毒患者, 症例 No. 5に打 ける腎機能 $\mathrm{Ccr}<20 \mathrm{ml} / \mathrm{min}$ での血清中・尿中パラ コート濃度の相関

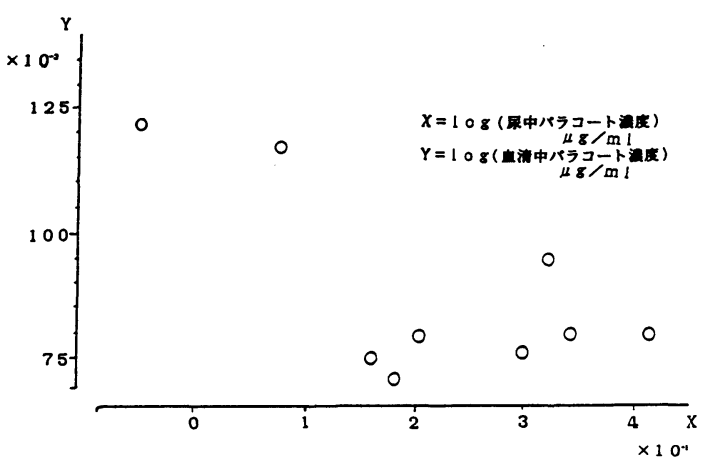

Table 2 尿中パラコート濃度の比色定性法による 半定量法の成績

\begin{tabular}{c|c|c|c}
\hline $\begin{array}{c}\text { 症例 } \\
\text { No. }\end{array}$ & $\begin{array}{c}\text { 定量尿中濃度 } \\
\mu \mathrm{g} / \mathrm{ml}\end{array}$ & $\begin{array}{c}\text { 半定量尿中推 } \\
\text { 定濃度 } \mu \mathrm{g} / \mathrm{ml}\end{array}$ & $\begin{array}{l}\text { 誤差 } \\
\%\end{array}$ \\
\hline 5 & 1400 & 1200 & 14.5 \\
7 & 155 & 130 & 16.1 \\
12 & 440 & 400 & 9.1 \\
31 & 220 & 200 & 9.1 \\
32 & 200 & 180 & 10.0 \\
\hline
\end{tabular}

$10 \sim 15 \mathrm{ml}$ 程度といわれている ${ }^{12)} .50 \mathrm{ml}$ 以上の服毒量 における救命率は $0 \%$ \%゙る ${ }^{113)}$ ，自験例でも同様の 結果を得た。しかし，服毒量の正確な判定は自殺企困 の場合には困難であり, 呕吐の量も関与するため服毒 量のみから重症度を推定することは困難である．実際 に，服毒量と生存率との間には相関がないという報告 が多( (3)14). そこで, 一般に重症度の判定には血清中パ ラコート濃度が使用されている。

血清中パラコート濃度から予後を判定する場合に は, 従来 Proudfoot の生存曲線が用いられて来たが, 明確な数量的基準は示されておらずグラフ上での判定 のため客観的に重症度を判定しにくかった. Hart ら ${ }^{15)}$ は219名のパラコート中毒患者の検討を括こない, 血中 濃度と服毒から測定までの時間との関係から $10 \%$ ～90\%の各生存曲線を算出しているが，これも明確な 数量的基準としては使用しにくかった。このような欠 点を補い，数量的客観的に重症度を判定し得る指標と してSIPPを考案し，その有用性については既に報告 した ${ }^{677)}$. 自験例ではSIPPにより病態はSIPP $\geqq 50$ 循 環不全死群, $50>\mathrm{SIPP} \geqq 10$ 呼吸不全死群, $10>\operatorname{SIPP}$ 生 
存群に分類できた。 また, SIPPは生存期間とも非常に 良く相関した ${ }^{7)}$.

このようにパラコート中毒の予後は現在血清中パラ コート濃度で予測されており, 尿中パラコート濃度か らその予後を予測する報告はほとんどない16). その理 由として，パラコート中毒の重症度を尿中パラコート 濃度で適確に表現しらる指標がなかったことと, 腎機 能の障害にともない尿中パラコートの排泄能が低下す ることが原因としてあげられる。そこで今回尿中パラ コート濃度から重症度を表わす指標として, 血清中パ ラコート濃度と経過時間から SIPPを考案したょう に，尿中パラコート濃度と経過時間から U-SIPP を考 案しその予後と生存時間について検討した。その結果, U-SIPP によっても生存群, 呼吸不全死群, 循環不全死 群の 3 群はU-SIPP が100 と 1,000 前後で分類できると 思われた. SIPP と同様に死亡例ではU-SIPP と生存 時間との間に相関があることが予想されたが, 死亡例 全体では相関はみられなかった。そこで腎機能障害の 程度による検討を試みた。腎機能の低下にともない， 他の薬剤と同様にパラコートの尿中排泄率も低下寸る と思われる。パラコートは分子量257の芳香性アミン で, 易水溶性で水溶液中では分子量186のパラコートイ オン17)となり血清蛋白とは漂とんど結合しない12)。 た，尿中にはほとんど代謝されずに未変化のまま排泄 される ${ }^{18) 19}$. 一方，クレアチニンの分子量は114である ことから腎機能障害時の腎からの排泄は注涪同様な傾 向をしめすと括もわれる。しかし, 腎に拈けるパラコー ト・クリアランスはクレアチニン・クリアランス值よ りも高値であり, パラコートは腎尿細管からの能動的 排泄もあると考兄られる ${ }^{20)}$. 一方, C cr と抗生剤の排泄 率では, Astromicin(分子量405) 200mg を人に筋注す ると $\mathrm{Ccr}<20 \mathrm{ml} / \mathrm{min}$ では高度の排泄障害と血中半減 期の延長がみられる ${ }^{21)}$. そこで, Ccr $20 \mathrm{ml} / \mathrm{min}$ 前後で 分けて尿中パラコート濃度と生存期間との相関を検討 した. その結果, Ccr $\geqq 20 \mathrm{ml} / \mathrm{min}$ では強い正の相関が みとめられた. loop利尿剤の furosemide は腎機能低

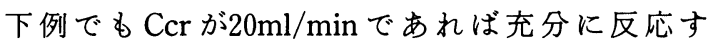
る $^{22)}$.このことから, 治療により利尿効果が得られる症 例では尿中濃度からも予後の推測ができるものと推定 された。

血清中パラコート濃度, 尿中パラコート濃度の両方 から予後の予測が可能であることが判明したので, 血 清中パラコート濃度と尿中パラコート濃度間の相関に ついても検討を行った。 その結果 $\mathrm{Ccr} \geqq 20 \mathrm{ml} / \mathrm{min} て ゙$
あれば両者間には強い正の相関がみられ，治療前では 尿中パラコート濃度は血清パラコート濃度の約 25 倍程 度であると判断された。 また， 1 症例のみの検討では あるが DHP 治療中の両者の相関についても検討をお こなった。 その結果, DHP 治療中でも $\mathrm{Ccr} \geqq 20 \mathrm{ml} / \mathrm{min}$ であれば両者間には強い正の相関がみとめられた。 た, このときの尿中パラコート濃度は血清パラコート 濃度の約 4.5 倍であった。 この尿中と血清中のパラコー トの比率が低下した理由として，パラコートが尿中へ 排泄される以外に DHP により血中から除去されるた めと考兄られ，この結果からもDHP の効果が充分あ ることが証明された. DHP の有効性の報告は多く ${ }^{14) 23)}$ Okonek らは 1 回 8 時間, $2 \sim 3$ 週間連続する continuous hemoperfusionが有効であったと報告してい る24). なた, DHPは来院後ただちに施行し, 少なくと も 3 回以上行わなければ効果は期待できないといら報 告25)もあるので, 可能な限り DHP を連続的に施行し た. しかし, DHPの limiting factorである血小板数 減少のために 24 時間以上連続施行できた症例は 1 例の みであった。 ほとんどの症例で血小板数が 5 万 $/ \mathrm{mm}^{3}$ 以下となり, 中止を余儀なくされた. Bismuth らはパ ラコートの除去法と予後について, 治療により生存率 を向上させることもできないし, 生存した症例でもパ ラコートの toxicokineticsを変えることはできな かったとしている26). しかし，DHPによる除去量は決 して少なくなく, 少なくとも borderline risk 群ならび に早期治療開始例には有効である ${ }^{14)}$. 自験例でも Bismuth $^{26)}$ の言うように初期のパラコート血中濃度が 予後を決定しているが, SIPPで示した境界領域の症 例は Proudfoot が示した救命曲線よりも上にあり, 血 中パラコートをさらに早急に除去し得る方法があれば 救命率を上げることが期待できるものと考えられる。

初診時 $\mathrm{Ccr} \geqq 20 \mathrm{ml} / \mathrm{min}$ では尿中パラコート濃度は 血清パラコート濃度の約 25 倍であった。そこでU. SIPP と予後との関係を再度検討すると尿中パラコー ト濃度が血清パラコート濃度の約 25 倍であることか ら, U-SIPP は250と1,250を予後の指標として概算で きる. 実際 Fig. 1 において Ccr $\geqq 20 \mathrm{ml} / \mathrm{min}$ の症例に ついて検討するとU.SIPP $\geqq 1,250$ 循環不全死群, $1,250>$ U-SIPP $\geqq 250$ 呼吸不全死群, $250>$ U-SIPP 生 存群とより細かく分類できた。

血清中のパラコート濃度の測定には時間を要し, 臨 㦿例に拁いて治療の指標として用いることは不便であ るためパラコート濃度の迅速な定量法が望まれてい 
た．従来簡易法として行われていた尿中パラコート定 性分析法では $1 \mu \mathrm{g} / \mathrm{ml}$ 以上の濃度が判定できる ${ }^{17)}$ 。こ の定性分析法を尿を希釈して測定する希釈比色法に応 用することにより, 簡便にかつ, 短時間で病棟で尿中 の濃度を半定量できた。定量法との誤差は $12 \%$ 前後で あるため, 利尿剂に反応して尿量が充分に増加する症 例ではこの比色法を用いて半定量的に測定した尿中濃 度からも拉拉よそのパラコート中毒患者の予後の予測 が可能であると打もわれた。

\section{結 語}

従来パラコート中毒患者の予後の予測は血清パラ コート濃度のみからおこなわれてきたが，尿中パラ コート濃度から予後予測が可能か否かについて検討し た。その結果以下の結論を得た。

1) 生存群, 呼吸不全死群, 循環不全死群で分類した 予後 3 群は $\mathrm{Ccr} \geqq 20 \mathrm{ml} / \mathrm{min}$ であれば SIPP と同様に U-SIPPによっても明瞭に分類可能であった.

2) $\mathrm{Ccr} \geqq 20 \mathrm{ml} / \mathrm{min}$ であれば生存時間と U-SIPP と の間には強い負の相関がみられた。

3) $\mathrm{Ccr} \geqq 20 \mathrm{ml} / \mathrm{min}$ であれば初診時の血清中パラ コート濃度と尿中パラコート濃度間には強い正の相関 がみられた。

4) $\mathrm{Ccr} \geqq 20 \mathrm{ml} / \mathrm{min}$ であれば, DHP 治療中でも血清 中パラコート濃度と尿中パラコート濃度間には強い正 の相関がみられた。

5）以上の結果から利尿剂に充分反応する症例であ れば，尿中パラコート定性分析法を応用した定性希釈 比色法を用いた半定量測定値から, 病棟で迅速にパラ コート中毒患者の予後の予測が可能であると思われ た.

稿を終えるにあたり, 御指導, 御校閲を賜りました恩師大 井好忠教授に深甚の謝意を表し, 終始御協力を頂いた鹿児 島大学医学部附属病院救急部の各位ならびに薬剤部本屋敏 郎先生に感謝申し上げます。

尚, 本論文の要旨は第76回日本泌尿器科学会総会, 第16回 日本救急医学会総会に扔いて報告した。

\section{文献}

1）武島玲子, 山下 衛, 毛利勝也, 中村紘一, 渡辺誠 治, 佐藤重不, 近藤陽一, 水谷太郎, 斎藤重行, 内 藤裕史, 横山孝一：ハララコート中毒の現状とその 対策. 救急医学, 7, 1827-1831，1983.

2）佐藤 威, 平賀聖悟, 飛田美穂, 上田守三：神奈川 県西湘地区に抢けるパラコート中毒の現況。日本 医事新報, No. 3262, 43-49, 1986.

3）千代孝夫, 和泉 宏, 淀沢 進, 泉田洋司, 内田健
一郎, 田中孝也：パラコート中毒に対する治療の 検討. 救急医学, 8, 207-214, 1984.

4）小野山薫, 高野健太郎, 武田一人：パラコート中 毒. 臨床と研究, 63, 2553-2558, 1986.

5) Proudfoot, A.T., Stewart, M.S., Levitt, T. and Widdop, B.: Paraquat poisoning ; significance of plasma-paraquat concentration. Lancet, 2, $330-332,1979$.

6）山本五十年, 永松 香, 広兼民徳, 永井義和, 上山 昌史, 澤田裕介, 本屋敏郎, 山下淳一：重症度指数 によるパラコート中毒者の重症度評価. 救急医学, 12, 453-454, 1988.

7）山下淳一, 大井好忠, 山本五十年, 澤田裕介, 本屋 敏郎：パラコート中毒症例の臨床的検討，とくに 重症度指数之予後について. 泌尿器外科, 1, 957-962, 1988 .

8）甲田 豊, 鈴木康化, 吉田和清, 下条文武, 荒川正 昭, 関 剛, 樽田 佐：パラコート中毒に対する 治療一メチルプレドニゾロンパルス療法と血液浄 化法の併用一日本医事新報, NO. 3101，43-47, 1983.

9) Shahar, E., Barzilay, Z. and ALADJEM, m.: Paraquat poisoning in a child: Vitamin $\mathrm{E}$ in amelioration of lung injury. Arch. Dis. Child., 55, 830-837, 1980.

10) Addo, E. and Poon-King, T.: Leucocute suppression in treatment of 72 patients with paraquat poisoning. Lancet, 17, 1117-1120, 1986.

11）本屋敏郎, 石橋丸應：パラコート中毒への対応の ために. 鹿児島県病院薬剤師会会誌, 23，13-17, 1986.

12) Conning, D.M., Fletcher, K. and Swan, A.A.B. : Paraquat and related bipyridyls. Br. Med. Bull., 25, 245-249, 1969 .

13）安藤義孝, 安藤公子, 土屋 智, 菅原健太郎, 尾形 真光, 吉田 智, 関口博行, 田野由子, 霞 利夫 : 急性パラコート中毒症例に対する腸洗浄法の有効 性について。透析会誌, 18, 365-370， 1985.

14）浅野 泰, 田部井薫, 武田和司, 草野英二：パラ コート中毒の治療. 救急医学, 11, 965-972, 1987.

15) Hart, T.B., Nevitt, A. and Whitehead, A.: A new statical approach to the prognostic significance of plasma paraquat concentrations. Lancet, 3, 1222-1223, 1984.

16) Scherrmann, J.M., Houze, P., Bismuth, C. and Bourdon, R. : Prognostic value of plasma and urine paraquat concentration. Human. Toxicol., 6, 91-93, 1987.

17） アイ・シー・アイ・ジャパン農薬部：グラモキソン 一中毒症状と処理法. アイ・シー・アイ・ジャパン, 1985.

18) Daniel, J.W. and Gage, J.C.: Absorption and 
excretion of siquat and paraquat in rats. Brit. J. Ind. Med., 23, 133-136, 1966.

19) Murray, R.E. and Gibson, J.E. : Paraquat disposition in rats, guinea pig and monkeys. Toxicol. Appl. Pharmacol., 27, 283-291, 1974.

20) Bismuth, C., Carnire, R., Dally, S. and Fournier, P.E. : Prognosis and treatment of paraquat poisoning-A review of 28 cases. J. Toxicol. -Clin. Toxicol., 19, 461-474, 1982.

21）山路武久：アミノ配糖体薬一吸収, 分布, 代謝, 排 泄. 上田 泰編集, p. 172-185, 南江堂, 1985 .

22) Berman, L.B. and Ebragimi, A.: Experience with furosemide in renal disease. Proc. Soc. Exp. Biol. Med., 118, 333-336, 1965.

23）西川 恵, 武藤秀雄, 久保和雄, 山下賀正, 佐中 改，太田和夫，杉野信博：Paraquat 中毒における paraquation の血中, 組織内動態とDirect Hemoperfusion の効果. 腎と透析, 12, 735-739, 1982.

24) Okonek, S., Baldamus, C.A., Hofmann, A., Schuster, C.J., Bechstein, P.B. and Zo'ller, B. : Two survivors of severe paraquat intoxication by "contineous hemoperfusion". Klin. Wochenschr., 57, 957-959, 1979.

25）鈴木幸一郎，田中 茂，小川寛之進，中村義博，広 瀬久昭, 藤井千穂, 小濱啓次, 橋本 淳, 新開洋一, 大沢源吾 : パラコート中毒の臨床検討. 救急医学, 10, 203-209, 1986.

26) Bismuth, C., Scherrmann, J.M., Garnier, R., Baud, F.J. and Pontal, P.G.: Elimination of paraquat. Human Toxicol., 6, 63-67, 1987.

（1989年 3 月 14 日受理，特別掲載） 